\title{
PENYELENGGARAAN PENANGGULANGAN BENCANA DI DESA KEMBANG KECAMATAN PACITAN KABUPATEN PACITAN
}

\author{
Rinawati, Annisa Mu'awanah Sukmawati \\ Program Studi Perencanaan Wilayah dan Kota Universitas Teknologi Yogyakarta \\ Jalan Glagahsari No.63 Yogyakarta 55164 - Telp. +62-274-623310 \\ e-mail: rinarinwa@gmail.com
}

\begin{abstract}
ABSTRAK
Desa Kembang adalah salah satu desa di Kabupaten Pacitan yang rentan mengalami bencana banjir. Desa Kembang telah ditetapkan sebagai Desa Tangguh Bencana (Destana) sejak tahun 2012. Meskipun dana tanggap darurat, dana untuk Pengurangan Risiko Bencana (PRB) untuk program Destana Desa Kembang sudah tersedia, dan penyelenggaraan pendanaan sudah dilakukan dengan baik, namun masih terdapat indikator-indikator pada penyelenggaraan penanggulangan bencana yang belum efektif. Artikel ini bertujuan untuk menilai penyelenggaraan penanggulangan bencana program Destana di Desa Kembang. Penelitian menggunakan metode kuantitatif melalui teknik analisis deskriptif kuantitatif dengan Skala Likert dan skoring. Indikator yang digunakan, meliputi peta dan kajian risiko, peta dan jalur evakuasi serta tempat pengungsian, sistem peringatan dini, pelaksanaan mitigasi struktural, pola ketahahan ekonomi masyarakat, perlindungan kesehatan pada kelompok rentan, pengelolaan sumber daya manusia untuk PRB, dan pengelolaan aset produktif masyarakat. Sumber data diperoleh dengan metode pengumpulan data primer melalui kuesioner, observasi, dan wawancara, serta metode pengumpulan data sekunder melalui telaah dokumen. Teknik pengambilan sampel menggunakan Stratified Random Sampling dengan jumlah sampel 100 responden, meliputi pemerintah desa, tim siaga dan tanggap bencana (TSB), Karang Taruna, serta masyarakat umum. Hasil penelitian menunjukkan bahwa penyelenggaraan penanggulangan bencana Desa Kembang melalui program Destana sudah efektif karena delapan indikator yang digunakan berada pada daerah respon efektif. Indikator yang paling efektif adalah ketersediaan peta dan jalur evakuasi, serta tempat pengungsian (74\%). Sedangkan indikator yang paling tidak efektif adalah perlindungan aset produktif utama masyarakat (63\%). Maka dapat disimpulkan bahwa, dari segi perencanaan penyelenggaraan penanggulangan bencana telah dipersiapkan dengan baik dengan membuat dokumen kajian risiko bencana dan tempat serta jalur evakuasi bencana. Namun, jika dilihat dari aspek ketahanan ekonomi atau terkait produktivitas masyarakat masih belum optimal. Padahal, aspek ekonomi adalah salah satu aspek yang paling terdampak bencana dan perlu diantisipasi langkah tindak lanjutnya. Diperlukan upaya dari pemerintah dan pemangku kepentingan lain dalam mencari alternatif ekonomi untuk ketahanan ekonomi masyarakat.
\end{abstract}

Kata Kunci : desa kembang, desa tangguh bencana, penanggunalan bencana

\begin{abstract}
Kembang Village is one of the villages in Pacitan District which is vulnerable to flooding. Kembang Village has been designated as a Disaster Resilient Village (Destana) since 2012. Even though the emergency response funds, funds for Disaster Risk Reduction (DRR) in Kembang Village program are available, and funding has been well implemented, but there are still indicators in the implementation of disaster management that have not been effective. This article aims to assess the implementation of the Destana disaster management program in Desa Kembang. The study employed quantitative methods through quantitative descriptive analysis techniques with a Likert Scale and scoring. Indicators used in research include maps and risk assessments, evacuation maps, routes and places of refuge, early warning systems, implementation of structural mitigation, patterns of community economic resilience, health protection for vulnerable groups, management of human resources for DRR, and management of productive assets Public. Sources of data obtained by primary data collection methods through questionnaires, observations, and interviews, and secondary data collection methods through document review. The sampling technique used Stratified Random Sampling with total samples of 100 respondents, consist of village government, disaster alert and response team, youth organization members, and the community. The results revealed that the implementation Destana in Kembang Village was effective because eight indicators used were in the effective response area. The most effective indicator is evacuation maps, routes, and places of refuge (74\%). While the most ineffective indicator is the protection of people's primary productive assets (63\%). So it can be concluded that in terms of planning the implementation of disaster management has been well prepared by making disaster risk assessment documents and disaster evacuation places and routes. However, when viewed from the aspect of economic security or related to community productivity is still not optimal. The economic aspect is one of the aspects most affected by disasters and it is necessary to anticipate follow-up steps. Therefore, the role of government and other stakeholders is needed in finding economic alternatives for community economic security.
\end{abstract}

Keywords: kembang village, disaster resilient village, disaster management 


\section{PENDAHULUAN}

Kabupaten Pacitan merupakan salah satu wilayah yang rawan terhadap bencana alam baik banjir, tsunami, gempa bumi, maupun tanah longsor. Pemerintah Kabupaten Pacitan melalui Badan Penanggulangan Bencana Daaerah (BPBD) mencanangkan program untuk mengantisipasi apabila terjadi bencana pada masa yang akan datang, yaitu program Desa Tangguh Bencana (Destana). Dalam Peraturan Kepala BNPB Nomor 1 Tahun 2012 tentang Pedoman Umum Desa/ Kelurahan Tangguh Bencana, Desa Tangguh Bencana diartikan sebagai desa yang memiliki kemampuan mandiri untuk beradaptasi dan menghadapi potensi ancaman bencana, serta memulihkan diri dengan segera dari dampak bencana yang merugikan. Ini menunjukkan bahwa program Destana ditujukan unutk mengurangi potensi dampak bencana dengan pembangunan dan memperkuat pengetahuan, partisipasi serta sistem regulasi masyarakat dan pemerintah desa untuk mengurangi risiko bencana melalui program pendampingan masyarakat dan aparatur tingkat desa.

Berdasarkan Peraturan Kepala BNPB Nomor 1 Tahun 2012, terdapat enam komponen dalam Desa/ Kelurahan Tangguh Bencana, yaitu 1) Legislasi yang terkait dengan ketersediaan peraturan desa yang mengatur pengurangan risiko dan penanggulangan bencana, 2) Perencanaan yang terkait dengan penyusunan rencana penanggulangan bencana, 3) Kelembagaan yang teridiri dari upaya pembentukan forum penanggulangan bencana, baik dari unsur pemerintah, masyarakat tim relawan, perangkat desa, RW dan RT, serta pemangku kepentingan lainnya, 4) Pendanaan, 5) Pengembangan Kapasitas, dan 6) Penyelenggaraan Penanggulangan Bencana. Secara spesifik, penyelenggaraan penanggulangan bencana terkait dengan kegiatan-kegiatan mitigasi fisik struktural dan non-fisik, sistem peringatan dini, kesiapsiagaan untuk tangggap darurat, dan segala upaya pengurangan risiko melalui intervensi pembangunan dan program pemulihan. Memahami penyelenggaraan penanggulangan bencana dapat membantu masyarakat untuk menemukenali potensi bencana, beradaptasi dan lebih resilien terhadap bencana tersebut (Rachmawati et al., 2018).

Di Indonesia, program Destana telah cukup berhasil membentuk masyarakat yang lebih berdaya dalam menghadapi bencana yang terjadi di sebuah daerah. Beberapa penelitian yang menunjukkan kesuksesan dari program Destana, seperti penelitian Setyawati \& Pambudi (2018) bahwa program Destana di Desa Argomulyo, Kabupaten Sleman efektif karena program sudah tepat sasaran baik bagi masyarakat, pemerintah, dan komunitas. Penelitian Pinakesti \& Husein, (2018) mengenai Destana di Desa Pondokrejo, Kabupaten Sleman juga menunjukkan hasil efektif karena aspek afektif/ pengetahuan dan kepedulian masyarakat terhadap program Destana tinggi. Namun demikian, ada juga Destana yang belum efektif, seperti penelitian Aini et al. (2018) di Desa Sirnoboyo, Kabupaten Pacitan yang menunjukkan bahwa beberapa faktor penyebab belum efektifnya program Destana adalah kapasitas SDM, keterbatasan pendanaan, dan belum adanya kerjasama dengan pelaku/ pihak lainnya dalam penanggulangan bencana. Padahal, program peningkatan kapasitas desa diperlukan untuk meningkatkan pemahaman masyarakat dan pemerintah desa untuk memahami bencana dan risikonya (Buchari et al., 2017; Oktari, 2019). Ini diperlukan agar masyarakat memiliki pemahaman dan kepedulian terhadap bencana (Susilowati \& Siswanta, 2016). Selain itu, penyelenggaraan penanggulangan bencana juga memerlukan koordinasi dari berbagai pihak untuk mengurangi risiko bencana dan membutuhkan peran dari multisektoral dan multistakeholder (Taslim \& Akbar, 2019).

Desa Kembang adalah salah satu desa di Kabupaten Pacitan yang ditetapkan sebagai Destana sejak tahun 2012. Penetapan ini dilatarbelakangi oleh posisi Desa Kembang yang terletak di wilayah pesisir Jawa Timur, yaitu di atas ketinggian 0-100 mdpl. Selain itu, Desa Kembang juga merupakan hilir Sungai Grindulu yang merupakan sungai terbesar di Kabupaten Pacitan dan rentan meluap. Bencana banjir dan longsor di Desa Kembang, terakhir terjadi pada tahun 2017 yang lalu. Idhom (2017) menyebutkan bahwa, kedua bencana ini disebabkan oleh cuaca ekstrem yang terjadi akibat pengaruh Siklon Tropis Cempaka yang berada di perairan sekitar $32 \mathrm{~km}$ sebelah selatan-tenggara Pacitan pada Selasa, 28 November 2017. Kekuatan badai siklon itu sekitar $65 \mathrm{~km}$ per jam. Cuaca ekstrem akibat pengaruh Siklon Tropis Cempaka memberikan dampak berat bagi Desa Kembang, karena berada di bagian selatan Kabupaten Pacitan sehingga dekat dengan jalur badai. Pada tahun yang sama, terdapat juga isu tsunami di Desa Kembang. Isu ini dipercayai masyarakat karena beredar setelah terjadi bencana banjir besar dan gempa bumi. Bahkan Bupati Pacitan turun lapangan untuk 
menghimbau warga Desa Kembang agar mengungsi.

Pemerintah Kabupaten Pacitan (2010) dalam RTRW Kabupaten Pacita Tahun 2009-2028 menjelaskan bahwa dominasi penguasaan lahan tegalan oleh penduduk setempat telah berdampak pada perkembangan kondisi tanah permukaan lahan DAS Grindulu, yaitu 61,29\% merupakan tanah dengan solum sangat tipis dan dijumpai singkapan batuan induk litosol. Kondisi demikian mengakibatkan mudah terkikisnya lapisan top soil yang berdampak pada tingginya tingkat sedimentasi yang terjadi di DAS Grindulu. Hal ini mengakibatkan Sungai Grindulu menjadi dangkal karena timbunan material di dalamnya dan mengurangi kemampuan sungai dalam menampung air. RTRW Kabupaten Pacitan Tahun 2009-2028 juga menunjukkan bahwa kurangnya daya tampung Sungai Grindulu berpengaruh terhadap Sungai Jelok. Sungai Jelok merupakan anak sungai terbesar dari Grindulu yang juga melewati Desa Kembang. Sungai Jelok sering kali meluap hingga mengakibatkan tanggul jebol.

Sejak ditetapkan sebagai Destana di tahun 2012, Desa Kembang mendapat dana tanggap darurat dan dana untuk Pengurangan Risiko Bencana (PRB). Pengelolaan pendanaan juga sudah dilakukan dengan baik. Namun, masih terdapat indikator lain pada penyelenggaraan penanggulangan bencana yang disinyalir belum belum efektif. Untuk itu, muncul pertanyaan penelitian, yaitu bagaimana pelaksanaan penyelenggaraan penanggulangan bencana melalui Program Destana di Desa Kembang? Tujuan penelitian adalah untuk menilai penyelenggaraan penanggulangan bencana program Destana di Desa Kembang. Penelitian dilakukan dengan delapan indikator yang diadaptasi dari Peraturan Kepala BNPB Nomor 1 Tahun 2012 yaitu peta dan kajian risiko, peta dan jalur evakuasi serta tempat pengungsian, sistem peringatan dini, pelaksanaan mitigasi struktural, pola ketahahan ekonomi masyarakat, perlindungan kesehatan pada kelompok rentan, pengelolaan sumber daya manusia untuk PRB, dan pengelolaan aset produktif masyarakat.

\section{METODE PENELITIAN}

Penelitian menggunakan metode penelitian kuantitiatif dengan teknik deskriptif kuantitatif. Metode penelitian kuantitatif adalah metode penelitian yang berlandaskan pada filsafat positivisme, digunakan untuk meneliti pada populasi atau sampel tertentu, pengumpulan data menggunakan instrument penelitian, analisis data bersifat statistik, dengan tujuan untuk menguji hipotesis yang telah ditetapkan (Sugiyono, 2016). Metode penelitian kuantitatif dipilih karena penelitian bertujuan untuk menilai atau mengukur penyelenggaraan penanggulangan bencana program Destana di Desa Kembang yang hasilnya akan disajikan dalam bentuk angka di jelaskan secara deskriptif.

Populasi dalam penelitian ini adalah warga Desa Kembang, Kecamatan Pacitan, Kabupaten Pacitan yaitu sebanyak 2.561 orang. Desa Kembang menjadi objek populasi karena desa ini merupakan salah satu desa yang rawan akan bencana alam di Kabupaten Pacitan, serta telah menerapkan program Desa Tangguh Bencana (Destana).

Besarnya sampel (ukuran sampel) dalam penelitian ini ditentukan dengan menggunakan Rumus Slovin sebagai berikut:

Dimana:

$$
n=\frac{\mathrm{N}}{1+N e^{2}}
$$

$\mathrm{e}=$ persentase tingkat error/

kesalahan $(1 \%, 5 \%, 10 \%)$

$\mathrm{n}=$ jumlah sampel

$\mathrm{N}=$ jumlah populasi

Penelitian ini menggunakan persentase error $10 \%$ yang berarti memiliki tingkat akurasi sebesar 90\%. Berdasarkan Rumus Slovin, maka diperoleh besar sampel sebagai berikut:

$$
\begin{aligned}
\mathrm{N} & =2.561 \\
n & =\frac{2.561}{1+2.561(0,1)^{2}} \\
n & =\frac{2.561}{1+25,61} \\
n & =\frac{2.561}{26,61} \\
n & =96,2 \\
n & =96 \\
n & =100 \text { (hasil pembulatan) }
\end{aligned}
$$

Dari hasil perhitungan tersebut, maka jumlah sampel representatif yang digunakan dalam penelitian ini adalah sebanyak 100 orang dari jumlah populasi sebanyak 2.561 orang.

Teknik pengambilan sampel dalam penelitian ini adalah menggunakan Stratified Random Sampling, yaitu teknik pengambilan sampel dari anggota populasi yang dilakukan melalui proses pembagian ke dalam strata, memilih sampel acak sederhana dari tiap stratum, dan menggabungkannya ke dalam sebuah sampel untuk menaksir parameter populasinya. Teknik sampel ini dipilih karena populasi pada penelitian bersifat heterogen dimana sampel harus mewakili setiap bagian dari populasi tersebut. 


\section{PENYELENGgARAAN PENANGgulangAN BENCANA DI DESA KEMBANG KECAMATAN PACITAN KABUPATEN PACITAN}

Stratified pada penelitian ini diaplikasikan dengan menstratakan berdasarkan peran. Strata pada penelitian ini kurang proporsional (Disproportionate) karena mengikuti keadaan di lapangan. Sampel pada Perangkat Desa, Karang Taruna, dan TIM TSB merupakan seluruh anggota kelompok, sedangkan sempel pada Masyarakat Umum merupakan tambahan untuk memenuhi jumlah sampel 100 orang. Strata pada penelitian dan distribusi sampel, yaitu:
1. Perangkat Desa
(22 orang)
2. Karang Taruna
(15 orang)
3. Kelompok Siaga Bencana (16 orang)
4. Masyarakat Umum
(47 orang)

Sumber data pada penelitian ini diperoleh dengan metode pengumpulan data primer dan sekunder. Pengumpulan data primer dilakukan dengan kuesioner, observasi lapangan, dan wawancara. Kuesioner diberikan kepada 100 orang responden yang memuat point-point pertanyaan sesuai dengan indikator di Tabel 1. Sementara itu, observasi dilakukan dengan observasi testruktur untuk menemukenali potensi bencana yang ada di Desa Kembang secara lebih mendalam serta untuk mengetahui wilayah mana yang paling rawan akan bencana alam di Desa Kembang. Wawancara dilakukan dengan wawancara semi terbuka yang ditujukan kepada pemerintah Desa Kembang, BPBD Kabupaten Pacitan, serta dinas lain terkait kebencanaan Desa Kembang.

Sementara itu, metode pengumpulan data sekunder dilakukan dengan telaah dokumen. Telaah dokumen ini bertujuan untuk menggali informasi tentang gambaran umum wilayah penelitian, peta Kawasan Rawan Bencana, kebijakan-kebijakan terkait penanggulangan resiko bencana, dokumen-dokumen perencanaan penanggulangan bencana, tentang pemetaan jalur evakuasi, anggaran desa untuk kegiatan pengurangan resiko bencana. Dokumen yang ditelaah pada penelitian ini adalah dokumendokumen perencanaan program Destana Kabupaten Pacitan Tahun 2012, Dokumen Rencana Tata Ruang Wilayah Kabupaten Pacitan Tahun 2009-2028, Profil Desa Kembang tahun 2019, serta Rencana Pembangunan Jangka Menengah Desa tahun 2018 - 2024.

Teknik analisis yang digunakan pada penelitian ini adalah analisis deskriptif dengan analisis Skala Likert dan skoring. Tolak ukur pada skala ini terbagi menjadi tiga kelas yaitu:
1. Tidak Efektif
2. Cukup
3. Efektif

Ketiga kelas tolak ukur ini didapatkan dari hasil perhitungan berikut:

Dimana:

$$
K=1+3,3 \log n
$$

K : banyaknya kelas

n : banyaknya indikator

Sehingga,

$$
\begin{aligned}
\mathrm{K} & =1+3,3 \log \mathrm{n} \\
& =1+3,3 \log 8 \\
& =1+2,9 \\
& =3,9 \approx 3 \text { kelas }
\end{aligned}
$$

Detail indikator dan tolak ukur dalam penyelenggaraan program penanggunalan

\begin{tabular}{|c|c|c|c|}
\hline \multirow{2}{*}{ Indikator } & \multicolumn{3}{|c|}{ Tolak Ukur } \\
\hline & Tidak Efektif (1) & Cukup (2) & Efektif (3) \\
\hline $\begin{array}{l}\text { Peta dan kajian } \\
\text { risiko }\end{array}$ & $\begin{array}{l}\text { Belum ada dokumen hasil } \\
\text { analisis risiko di desa. }\end{array}$ & $\begin{array}{l}\text { Ada dokumen hasil analisis risiko di } \\
\text { desa, namun belum berdampak pada } \\
\text { berkurangnya risiko. }\end{array}$ & $\begin{array}{lr}\text { Ada kegiatan-kegiatan di } \\
\text { desa/kelurahan } & \text { yang } \\
\text { dilaksanakan berdasarkan hasil } \\
\text { analisis risiko bencana, yang } \\
\text { kemudian berdampak pada } \\
\text { berkurangnya risiko }\end{array}$ \\
\hline $\begin{array}{l}\text { Peta dan jalur } \\
\text { evakuasi, serta } \\
\text { tempat } \\
\text { pengungsian }\end{array}$ & $\begin{array}{l}\text { Sudah ada peta dan jalur } \\
\text { evakuasi, namun belum } \\
\text { menyediakan } \\
\text { evakuasi khusus sebagai } \\
\text { tempat pengungsian ketika } \\
\text { terjadi bencana. }\end{array}$ & $\begin{array}{l}\text { Sudah ada peta dan jalur evakuasi, } \\
\text { serta tempat pengungsian sudahdi } \\
\text { tentukan dan dilengkapi dengan } \\
\text { perlengkapan dasar seperti P3K, } \\
\text { obat-obatan, penerangan darurat } \\
\text { namun belum ada simulasi evakuasi. }\end{array}$ & $\begin{array}{l}\text { Sudah sering dilakukan praktik } \\
\text { simulasi evakuasi } \\
\text { penyelamatan diri bersama } \\
\text { warga desa }\end{array}$ \\
\hline
\end{tabular}
bencana pada program Destana di Desa Kembang dilihat pada Tabel 1 .

Tabel 1. Indikator dan tolak ukur efektivitas penyelenggaraan penanggulangan bencana pada program Destana Desa Kembang 


\begin{tabular}{|c|c|c|c|}
\hline \multirow{2}{*}{ Indikator } & \multicolumn{3}{|c|}{ Tolak Ukur } \\
\hline & Tidak Efektif (1) & Cukup (2) & Efektif (3) \\
\hline $\begin{array}{l}\text { Sistem } \\
\text { peringatan dini }\end{array}$ & $\begin{array}{l}\text { Belum dilengkapi dengan } \\
\text { data/informasi, peralatan } \\
\text { dan personil yang } \\
\text { memadai. }\end{array}$ & $\begin{array}{l}\text { Sudah dilengkapi dengan } \\
\text { data/informasi, peralatan dan } \\
\text { personil yang memadai untuk } \\
\text { menjalankan fungsinya, serta } \\
\text { mekanisme penyampaian informasi } \\
\text { yang cepat, akurat dan jelas kepada } \\
\text { seluruh warga namun belum ada } \\
\text { praktik simulasi. }\end{array}$ & $\begin{array}{l}\text { Sudah sering dilakukan praktik } \\
\text { simulasi pelaksanaan sistem } \\
\text { peringatan dini bersama warga } \\
\text { desa/kelurahan. }\end{array}$ \\
\hline $\begin{array}{l}\text { Pelaksanaan } \\
\text { mitigasi } \\
\text { struktural (fisik) }\end{array}$ & $\begin{array}{lr}\text { Belum ada } & \text { kegiatan } \\
\text { pembangunan } & \text { fisik } \\
\text { (mitigasi) } & \text { yang } \\
\text { dilaksanakan } & \text { untuk } \\
\text { mengurangi risiko bencana } \\
\text { di desa. }\end{array}$ & $\begin{array}{l}\text { Sudah ada kegiatan pembangunan } \\
\text { fisik (mitigasi) yang dilaksanakan } \\
\text { untuk mengurangi risiko bencana di } \\
\text { desa, sepertir memperkuat } \\
\text { tanggul.sungai, ranecah } \\
\text { gelombang, bangunan tahan gempa } \\
\text { namun belum ada mekanisme } \\
\text { pengelolaan dan pemeliharaannya }\end{array}$ & $\begin{array}{l}\text { Sudah ada mekanisme } \\
\text { pengelolaan dan pemeliharaan } \\
\text { pembangunan fisik tersebut } \\
\text { untuk menjamin kelestariannya } \\
\text { serta upaya untuk menyebar- } \\
\text { luaskannya. }\end{array}$ \\
\hline $\begin{array}{l}\text { Pola ketahanan } \\
\text { ekonomi untuk } \\
\text { mengurangi } \\
\text { kerentanan } \\
\text { masyarakat }\end{array}$ & 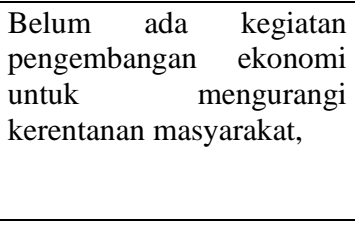 & $\begin{array}{l}\text { Sudah ada kegiatan-kegiatan } \\
\text { pengembangan ekonomi yang } \\
\text { dilaksanakan untuk mengurangi } \\
\text { kerentanan masyarakat namun } \\
\text { belum ada mekanisme keberlanjutan } \\
\text { program. }\end{array}$ & $\begin{array}{lr}\text { Sudah ada } & \text { mekanisme untuk } \\
\text { menjamin } & \text { keberlanjutan } \\
\text { pengembangan ekonomi. }\end{array}$ \\
\hline $\begin{array}{l}\text { Perlindungan } \\
\text { kesehatan } \\
\text { kepada } \\
\text { kelompok } \\
\text { rentan }\end{array}$ & 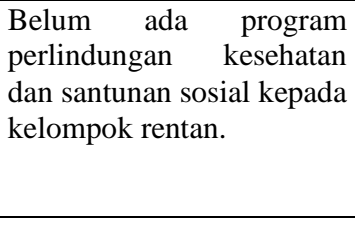 & $\begin{array}{l}\text { Sudah ada skema program } \\
\text { perlindungan kesehatan dan } \\
\text { santunan sosial kepada kelompok } \\
\text { rentan namun belum ada pengelola, } \\
\text { mekanisme dan prosedur } \\
\text { pelaksanaan program }\end{array}$ & $\begin{array}{lrr}\text { Sudah ada } & \text { pengelola, } \\
\text { mekanisme } & \text { dan } & \text { prosedur } \\
\text { pelaksanaan } & & \text { program } \\
\text { perlindungan } & \text { kesehatan dan } \\
\text { santunan sosial kepada } \\
\text { kelompok-kelompok rentan }\end{array}$ \\
\hline $\begin{array}{l}\text { Pengelolaan } \\
\text { SDM untuk } \\
\text { PRB }\end{array}$ & $\begin{array}{l}\text { Belum ada kegiatan- } \\
\text { kegiatan } \\
\text { sumber daya alam. }\end{array}$ & $\begin{array}{l}\text { Sudah ada kegiatan-kegiatan } \\
\text { pengelolaan sumber daya alam } \\
\text { sebagai upaya pengurangan risiko } \\
\text { bencana namun belum ada } \\
\text { mekanisme } \\
\text { pengelolaan. }\end{array}$ & $\begin{array}{l}\text { Sudah ada mekanisme untuk } \\
\text { menjamin keberlanjutan } \\
\text { pengelolaan sumber daya alam } \\
\text { untuk pengurangan risiko } \\
\text { bencana dalam kurun waktu } \\
\text { yang panjang. }\end{array}$ \\
\hline $\begin{array}{l}\text { Pengelolaan aset } \\
\text { produktif utama } \\
\text { masyarakat }\end{array}$ & $\begin{array}{l}\text { Belum ada pengelolaan } \\
\text { aset produktif masyarakat }\end{array}$ & $\begin{array}{l}\text { Ada kegiatan yang jelas untuk } \\
\text { melakukan perlindungan aset } \\
\text { produktif masyarakat seperti } \\
\text { asuransi komunitas, gudang } \\
\text { Bersama namun belum ada } \\
\text { mekanisme untuk menjalankan dan } \\
\text { memelihara aset. }\end{array}$ & $\begin{array}{l}\text { Ada pengelola dan mekanisme } \\
\text { yang jelas untuk menjalankan } \\
\text { dan memelihara perlindungan } \\
\text { aset produktif masyarakat. }\end{array}$ \\
\hline
\end{tabular}

Sumber: Perka BNPB Nomor 1 Tahun 2012 tentang Pedoman Umum Desa/Kelurahan Tangguh Bencana. 2012

Analisis skoring yang dimaksud pada penelitian ini adalah analisis hasil pengisian kuesioner indikator penilaian efektivitas program Destana. Tujuan analisis skoring ini adalah untuk menentukan tingkat efektivitas penyelenggaraan penanggulangan bencana pada program Destana Desa Kembang. Skoring dalam penelitian ini ditentukan dengan perhitungan sebagai berikut:

\section{a) Penentuan Skor Responden}

Menurut Sugiyono (2016) hal pertama yang harus dilakukan dalam analisis skoring adalah menentukan skor dari tiap respon yang akan diberikan. Skor respon pada penelitian ini ditentukan seperti pada Tabel 2.

\section{Tabel 2. Skor responden}

\begin{tabular}{ll}
\hline Skala Respon & Skor \\
\hline Tidak Efektif (TE) & 1 \\
\hline Cukup Efektif (CE) & 2 \\
\hline Efektif $(\mathrm{E})$ & 3 \\
\hline
\end{tabular}

b) Skor Ideal

Skor ideal ini digunakan untuk menentukan rating scalei dan jumlah total respon. Untuk menghitung skor ideal, maka digunakan rumus berikut:

\section{Skor Ideal $=$ Nilai skala $\mathrm{x}$ Total respon}

Skor tertinggi dalam penelitian ini adalah 3 , sehingga dapat dirumuskan menjadi seperti pada Tabel 3. 


\section{Tabel 3. Skor Ideal}

\begin{tabular}{ll}
\hline Rumus & Skala \\
\hline $3 \times 100=300$ & E \\
\hline $2 \times 100=200$ & CE \\
\hline $1 \times 100=100$ & TE \\
\hline
\end{tabular}

Selanjutnya, semua respon dijumlahkan dan dimasukkan ke dalam rating scale untuk menentukan daerah responnya.

\section{c) Rating Scale}

Skor yang telah diperoleh dimasukkan ke dalam rating scale sebagai berikut:

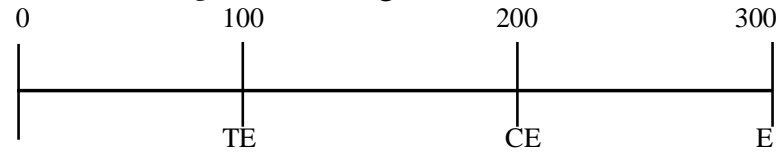

Daerah respon pada rating scale di atas dapat dijabarkan menjadi seperti pada Tabel 4.

Tabel 4. Rating scale

\begin{tabular}{ll}
\hline Nilai Respon & Skala \\
\hline $201-300$ & E \\
\hline $101-200$ & CE \\
\hline $1-100$ & TE \\
\hline
\end{tabular}

\section{d) Hasil Akhir}

Hasil akhir dalam penelitian ini ditentukan dengan menjumlahkan seluruh skor dari semua respon dengan rumus:

\begin{tabular}{ll} 
Responden E x 3 & $=\mathrm{n}$ \\
Responden CE x 2 & $=\mathrm{n}$ \\
Responden TE x 1 & $=\mathrm{n}$ \\
\hline Skor Total & $=\sum \mathrm{n}$
\end{tabular}

Hasil $\sum \mathrm{n}$ dicocokkan dengan rating scale. Untuk itu, akan diketahui daerah responnnya.

\section{HASIL DAN PEMBAHASAN}

\section{Profil Desa Kembang}

Penelitian ini dilaksanakan di Desa Kembang, Kecamatan Pacitan, Kabupaten Pacitan, Jawa Timur. Pada umumnya, wilayah Kecamatan Pacitan sebagian besar berupa dataran rendah di sekitar teluk Pacitan, serta dikelilingi oleh pegunungan dan perbukitan. Untuk mengetahui lokasi penelitian secara jelas dapat dilihat pada Gambar 1.

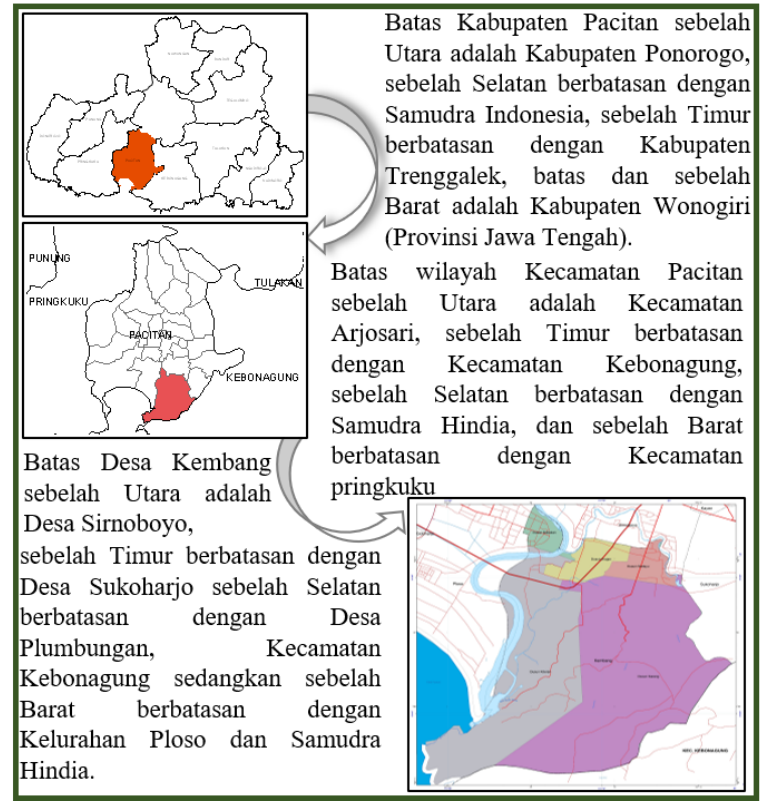

Gambar 1. Konstelasi Wilayah Amatan

Desa Kembang terbagi menjadi lima dusun yaitu Dusun Krajan sebagai pusat pemerintahan desa, Dusun Bubakan, Dusun Karang, dusun Sedayu, serta Dusun Kiteran yang merupakan dusun terluas di Desa Kembang.

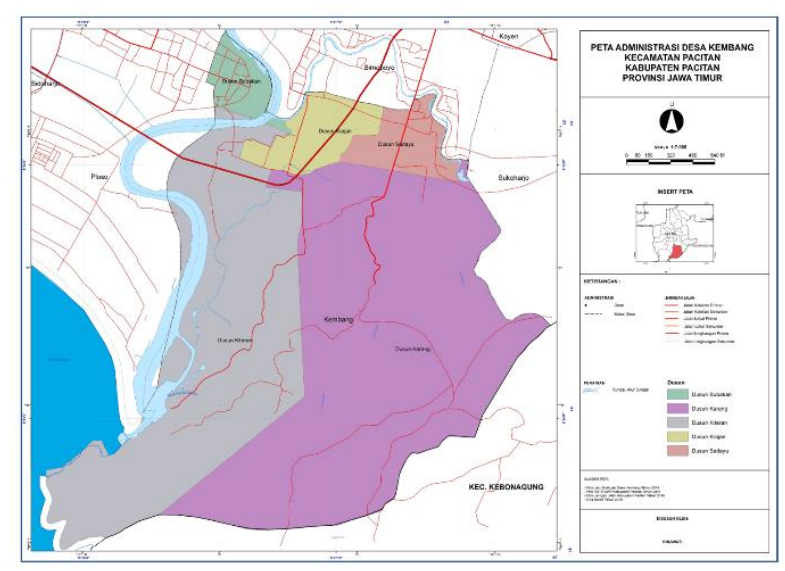

Gambar 2. Peta Administrasi Desa Kembang

Jumlah penduduk Desa Kembang pada tahun 2019 menurut BPS (2000) adalah 2.561 orang dengan penduduk laki-laki sebanyak 1.273 orang dan penduduk perempuan sebanyak 1.288 orang. Jumlah penduduk sebanyak 2.561 orang tersebut terbagi menjadi 787 kepala keluarga. Desa Kembang memiliki kepadatan penduduk sejumlah $615,28 / \mathrm{km}^{2}$.

Tingkat Pendidikan penduduk di Desa Kembang paling dominan adalah tamat SD sederajat, yaitu sebanyak 710 orang. Sedangkan tingkat pendidikan paling sedikit adalah tamat D1 dan S-2, yaitu lima orang. 
Penduduk usia kerja di Desa Kembang adalah sebanyak 1.816 orang. Desa Kembang didominasi oleh penduduk bermatapencaharian sebagai nelayan. Hal ini sejalam dengan letak Desa Kembang yang berada di wilayah pesisir. Secara keseluruhan jenis pekerjaan yang ada di Desa Kembang antara lain adalah petani (445 orang), buruh tani (364 orang), buruh migran (2 orang), PNS (29 orang), nelayan (512 orang), TNI (4 orang), POLRI (2 orang), dosen swasta (1 orang), pedagang keliling (3 orang), pembantu rumah tangga (3 orang), karyawan swasta (426 orang), karyawan perusahaan pemerintah 14 orang, dan pensiunan (11 orang).

\section{Potensi Bencana di Desa Kembang}

Desa Kembang terdiri dari dataran rendah yaitu 70,00 Ha, Kawasan tepi pantai seluas 10,00 Ha, kawasan rawa seluas 0,10 Ha, Kawasan aliran sungai seluas 50,00 Ha, serta Kawasan bantaran sungai seluas 90,00 Ha. Desa Kembang berada pada zona merah kawasan risiko bencana, terutama tsunami dan banjir. Ini dikarenakan lokasi geografis Desa Kembang yang terletak di pesisir serta menjadi hilir dari Sungai Grindulu. Potensi kerawanan bencana di Desa Kembang meliputi bencana gempa bumi, tsunami, tanah longsor, dan banjir.

Adapun penjelasan dari ragam potensi bencana lain yang ditemukan di Desa Kembang sebagai berikut:

\section{a) Gempa Bumi}

Hasil wawancara dengan BPBD Kabupaten Pacitan dan telaah dokumen Kajian Resiko Bancana Kabupaten Pacitan Tahun 2014-2018, menunjukkan bahwa Desa Kembang berada di Kawasan Koridor Pantai Selatan Jawa. Kawasan koridor Pantai Selatan Jawa merupakan bagian dari Lempeng Eurasia di bagian utara garis equator yang mempunyai potensi tumbukan (subduktif aktif) dengan Lempeng Indo-Australia di bagian selatan garis equator pada Samudera Hindia. Potensi tumbukan ini dapat menimbulkan gempa tektonik, mengingat gerakan alami lempeng menuju garis equator sebagai akibat gaya sentrifugal putaran bola bumi. Desa Kembang termasuk dalam wilayah kawasan rawan bencana gempa bumi sedang dan tinggi. Desa Kembang merupakan kawasan yang berpotensi terlanda goncangan gempa bumi dengan intensitas lebih dari VIII MMI (Modified Mercalli Intensity). Gempa bumi dengan intensitas VIII MMI (Modified Mercalli Intensity) berarti, gempa bumi yang dapat mengakibatkan kerusakan ringan pada bangunan dengan konstruksi yang kuat, retakretak pada bangunan dengan konstruksi kurang baik, dinding dapat lepas dari rangka rumah, cerobong asap pabrik dan monumen-monumen roboh, serta air menjadi keruh. Kawasan Desa Kembang berpotensi terjadi retakan tanah, pelulukan, longsoran pada tebing terjal dan pergeseran tanah. Percepatan gempa bumi lebih besar dari $0.34 \mathrm{~g}$. Berdasarkan batuan, daerah ini tersusun oleh aluvium, endapan gunung api, dan batuan yang telah terlapukkan secara kuat.

Kawasan rawan bencana gempa bumi tinggi Desa Kembang adalah di Dusun Bubakan, Dusun Krajan, Dusun Sedayu, dan sebagian dari Dusun Kiteran dan Dusun Karang. Sedangkan Sebagian lain dari Dusun Kiteran dan Dusun Karang merupakan kawasan rawan bencana gempa bumi sedang. Kawasan rawan bencana gempa bumi di Desa Kembang dapat dilihat pada Gambar 3.

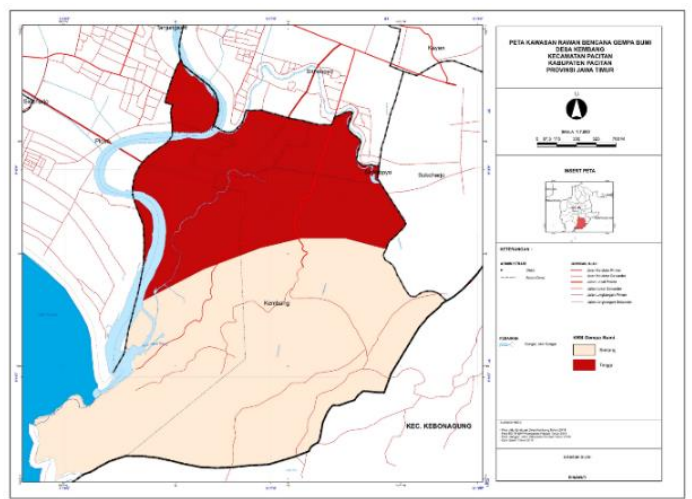

\section{Gambar 3. Peta Kawasan Rawan Bencana Gempa Bumi di Desa Kembang}

\section{b) Tsunami}

Desa Kembang merupakan salah satu kawasan yang rawan akan bencana tsunami dan perlu diatur penggunaan lahannya. Karena merupakan kawasan yang terletak di bagian Selatan dengan kemiringan lahan yang landai sekitar 0-15\%. Desa Kembang terletak di pesisir Samudra Hindia. Kawasan rawan bencana tsunami di Desa Kembang dapat dilihat pada Gambar 4.

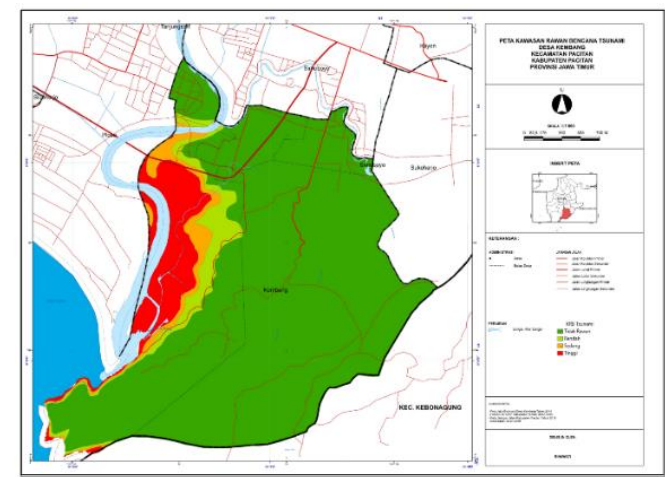

Gambar 4. Peta Kawasan Rawan Bencana Tsunami di Desa Kembang 
c) Tanah Longsor

Desa Kembang berada pada tingkat kerawanan longsor sangat rendah hingga tinggi. Kawasan rawan bencana longsor sangat rendah Desa Kembang adalah pada dataran rendah, yaitu

Dusun Bubakan, Dusun Krajan, Dusun Sedayu, serta Sebagian dari Dusun Kiteran dan Dusun Karang. Sedangkan seluruh dataran tinggi Desa Kembang, yaitu perbukitan yang membentang dari Dusun Karang hingga Dusun Krajan merupakan kawasan rawan bencana longsor rendah hingga tinggi. Kawasan rawan bencana tanah longsor Desa Kembang dapat dilihat pada Gambar 5.

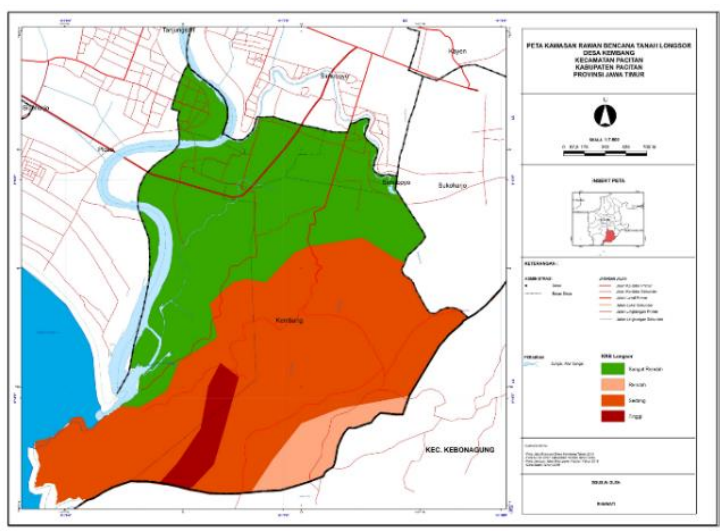

Gambar 5. Peta Kawasan Rawan Bencana Tanah Longsor di Desa Kembang

d) Banjir

Kerawanan banjir di Desa Kembang Pola merupakan kelas rendah. Kerawanan ini terjadi di seluruh dataran rendah Desa Kembang. Sehingga, semua permukiman di Desa Kembang rawan terhadap bencana banjir. Sedangkan kawasan yang tidak rawan terhadap banjir adalah perbukitan yang membentang dari di Dusun Karang hingga Dusun Kiteran. Kawasan rawan bencana banjir di Desa Kembang dapat dilihat pada Gambar 6.

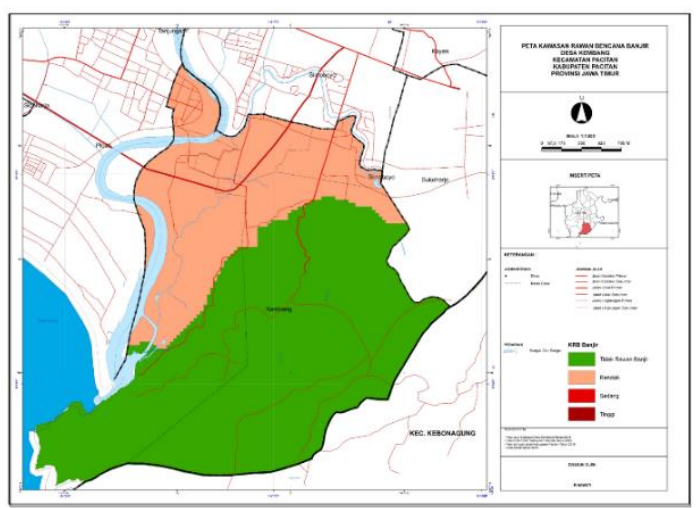

Gambar 6. Peta Kawasan Rawan Bencana Banjir di Desa Kembang
Hasil penilaian dengan analisis Skala Likert dan skoring mengenai penyelenggaraan penanggulangan bencana pada program Destana di Desa Kembang diukur dengan menghitung skor 100 responden sebagaimana hasil di Tabel 5.

Tabel 5. Efektivitas penyelenggaraan penanggulangan bencana pada program Destana Desa Kembang

\begin{tabular}{|c|c|c|c|c|c|}
\hline Indikator & $\begin{array}{l}\text { Tolak } \\
\text { Ukur }\end{array}$ & $\begin{array}{c}\text { Perang } \\
\text { kat } \\
\text { Desa }\end{array}$ & $\begin{array}{l}\text { TIM } \\
\text { TSB }\end{array}$ & $\begin{array}{c}\text { Kar- } \\
\text { ang } \\
\text { Taru- } \\
\text { na }\end{array}$ & $\begin{array}{c}\text { Masya- } \\
\text { rakat } \\
\text { Umum }\end{array}$ \\
\hline \multirow{3}{*}{$\begin{array}{l}\text { Peta dan } \\
\text { Kajian } \\
\text { Risiko }\end{array}$} & $\begin{array}{c}\text { Tidak } \\
\text { Efektif }\end{array}$ & 0 & 0 & 5 & 17 \\
\hline & $\begin{array}{l}\text { Cukup } \\
\text { Efektif }\end{array}$ & 0 & 0 & 0 & 10 \\
\hline & Efektif & 22 & 16 & 10 & 20 \\
\hline \multirow{3}{*}{$\begin{array}{l}\text { Peta dan } \\
\text { jalur } \\
\text { evakuasi, } \\
\text { serta } \\
\text { tempat } \\
\text { pengungsia } \\
\text { n }\end{array}$} & $\begin{array}{c}\text { Tidak } \\
\text { Efektif }\end{array}$ & 0 & 1 & 4 & 4 \\
\hline & $\begin{array}{l}\text { Cukup } \\
\text { Efektif }\end{array}$ & 0 & 3 & 3 & 1 \\
\hline & Efektif & 22 & 12 & 8 & 32 \\
\hline \multirow{3}{*}{$\begin{array}{l}\text { Sistem } \\
\text { Peringatan } \\
\text { Dini }\end{array}$} & $\begin{array}{c}\text { Tidak } \\
\text { Efektif }\end{array}$ & 0 & 3 & 6 & 18 \\
\hline & $\begin{array}{l}\text { Cukup } \\
\text { Efektif }\end{array}$ & 22 & 3 & 5 & 10 \\
\hline & Efektif & 0 & 10 & 4 & 19 \\
\hline \multirow{3}{*}{$\begin{array}{l}\text { Pelaksanaa } \\
\text { n mitigasi } \\
\text { struktural } \\
\text { (fisik) }\end{array}$} & $\begin{array}{c}\text { Tidak } \\
\text { Efektif }\end{array}$ & 0 & 1 & 3 & 10 \\
\hline & $\begin{array}{l}\text { Cukup } \\
\text { Efektif }\end{array}$ & 0 & 3 & 4 & 12 \\
\hline & Efektif & 22 & 12 & 8 & 25 \\
\hline \multirow{3}{*}{$\begin{array}{l}\text { Pola } \\
\text { ketahanan } \\
\text { ekonomi } \\
\text { untuk } \\
\text { mengurangi } \\
\text { kerentanan } \\
\text { masyarakat }\end{array}$} & $\begin{array}{c}\text { Tidak } \\
\text { Efektif }\end{array}$ & 0 & 7 & 10 & 32 \\
\hline & $\begin{array}{l}\text { Cukup } \\
\text { Efektif }\end{array}$ & 0 & 4 & 4 & 8 \\
\hline & Efektif & 22 & 5 & 1 & 7 \\
\hline \multirow{3}{*}{$\begin{array}{l}\text { Perlindung } \\
\text { an } \\
\text { Kesehatan } \\
\text { kepada } \\
\text { Kelompok } \\
\text { Rentan } \\
\end{array}$} & $\begin{array}{c}\text { Tidak } \\
\text { Efektif }\end{array}$ & 0 & 1 & 4 & 13 \\
\hline & $\begin{array}{l}\text { Cukup } \\
\text { Efektif }\end{array}$ & 0 & 3 & 5 & 8 \\
\hline & Efektif & 22 & 12 & 6 & 26 \\
\hline \multirow{3}{*}{$\begin{array}{l}\text { Pengelolaa } \\
\text { n SDM } \\
\text { untuk PRB }\end{array}$} & $\begin{array}{c}\text { Tidak } \\
\text { Efektif }\end{array}$ & 0 & 4 & 5 & 25 \\
\hline & $\begin{array}{l}\text { Cukup } \\
\text { Efektif }\end{array}$ & 0 & 4 & 5 & 11 \\
\hline & Efektif & 22 & 8 & 5 & 11 \\
\hline \multirow{3}{*}{$\begin{array}{l}\text { Pengelolaa } \\
\mathrm{n} \text { aset } \\
\text { produktif } \\
\text { utama } \\
\text { masyarakat }\end{array}$} & $\begin{array}{c}\text { Tidak } \\
\text { Efektif }\end{array}$ & 22 & 6 & 8 & 27 \\
\hline & $\begin{array}{l}\text { Cukup } \\
\text { Efektif }\end{array}$ & 0 & 1 & 1 & 1 \\
\hline & Efektif & 0 & 9 & 6 & 19 \\
\hline
\end{tabular}

1) Peta dan Kajian Risiko

Dari Tabel 5, sebanyak 68\% responden menyebutkan bahwa pata dan kajian risiko kebencanaan Desa Kembang sudah efektif. Hal ini sebabkan karena di Desa Kembang sudah 
dilakukan analisis risiko bencana desa oleh BPBD. Adanya upaya analisis risiko ini berdampak pada berkurangnya risiko bencana Desa Kembang. Dengan adanya analisis risiko ini, masyarakat maupun pemerintah desa menjadi lebih memahami dan meningkatkan kesadaran terkait ancaman bencana yang ada di wilayahnya sehingga dapat dijadikan dasar dalam penyelenggaraan pemerintahan desa. Meskipun demikian, masih ada $32 \%$ responden yang menyatakan bahwa peta dan kajian risiko di Desa Kembang belum efektif. Hal ini dikarenakan oleh ketidaktahuan dari beberapa kelompok masyarakat terkait keberadaan peta maupun kajian risiko. Untuk itu, penyebaran informasi mengenai ketersediaan dokumen risiko bencana bukan hanya tanggung jawab dari pemerintah selaku pembuat dokumen kebijakan, namun masyarakat juga perlu turut serta aktif mencari tahu mengenai dokumen analisis risiko tersebut.

2) Peta dan Jalur Evakuasi, serta Tempat Pengungsian

Dari 100 responden, sebanyak $74 \%$ menyebutkan bahwa peta dan jalur evakuasi, serta tempat pengungsian pada program Destana Desa Kembang telah efektif. Desa Kembang telah memiliki peta jalur evakuasi serta tempat pengungsian yang dilengkapi dengan perlengkapan dasar seperti P3K, obat-obatan, serta penerangan darurat. Meskipun demikian, masih ada $26 \%$ responden yang menyatakan bahwa Peta dan Jalur Evakuasi, serta tempat pengungsian di Desa Kembang belum efektif. Hal ini dikarenakan oleh ketidaktahuan dari beberapa kelompok masyarakat terkait keberadaan Peta dan Jalur Evakuasi, serta tempat pengungsian tersebut.

Peta jalur evakuasi bencana Desa Kembang tersebar di dua titik, yaitu di Dusun Kiteran dan Dusun Sedayu. Pada tahun 2014, peta jalur evakuasi bencana Desa Kembang dicetak pada kertas dan dibagikan ke rumah-rumah warga yang kemudian ditempelkan. Hal itu merupakan bentuk sosialisasi pemerintah desa terkait evaluasi bencana Desa kembang. Sedangkan tempat pengungsian terletak di Dusun Sedayu yang diberi nama Kepang Rono, serta terletak di Dusun Karang yang diberi nama Watu Gupit (lihat Gambar 7).

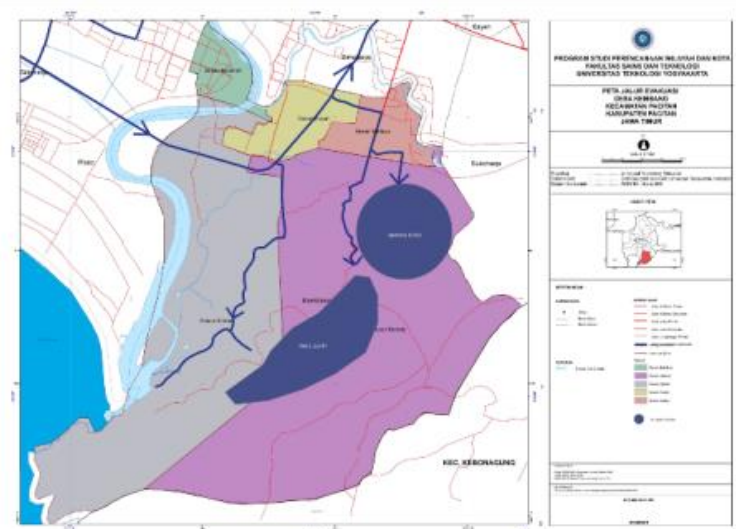

\section{Gambar 7. Peta dan jalur evakuasi dan tempat pengungsian Desa Kembang}

\section{3) Sistem Peringatan Dini}

Dari 100 responden, sebanyak $40 \%$ menyebutkan bahwa sistem peringatan dini di Desa Kembang cukup efektif. Sistem peringatan dini di Desa Kembang sudah dilengkapi dengan data atau informasi, peralatan dan personil yang memadai untuk mejalankan fungsinya, serta mekanisme penyampaian informasi yang cepat, akurat, dan jelas kepada seluruh warga. Namun di Desa Kembang belum sering dilakukan praktik simulasi pelaksanaan sistem peringatan dini bersama warga desa. Penyampaian informasi kebencanaan dilengkapi dengan Handy Talky (HT), kentongan, serta Sirine. Sirine Desa Kembang terletak di Dusun Bubakan (Gambar 8).

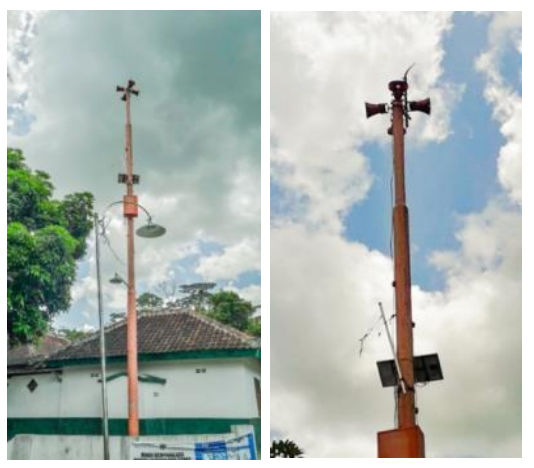

\section{Gambar 8. Sirine di Desa Kembang}

4) Pelaksanaan Mitigasi Struktural (Fisik)

Berdasarkan hasil skoring terhadap 100 responden, sebanyak $67 \%$ responden menyatakan bahwa pelaksanaan mitigasi struktural di Desa Kembang telah efektif. Hal itu ditandai dengan adanya kegiatan pembangunan fisik (mitigasi) yang dilaksanakan untuk mengurangi risiko bencana di desa seperti memperkuat tanggul sungai serta sudah ada mekanisme pengelolaan dan pemeliharaan pembangunan fisik tersebut untuk menjamin kelestariannya serta upaya untuk menyebarluaskannya. Perbaikan tanggul jebol di 
Dusun Kiteran sepanjang 90 meter telah dialokasikan dalam anggaran tahun 2020.

Pembangunan tanggul ini terintegrasi dengan Desa Sirnuboyo yang sama-sama berlokasi di hilir Sungai Grindulu. Pembangunan tanggul tanggul menggunakan dana APBD serta dana dari pemerintah pusat yang dikoordinasi oleh Balai Besar Wilayah Sungai (BBWS) Bengawan Solo.

5) Pola Ketahanan Ekonomi untuk Mengurangi Kerentanan Masyarakat

Dari 100 responden, sebesar 49\% responden mengatakan bahwa pola ketahanan ekonomi untuk mengurangi kerentanan masyarakat di Desa Kembang kurang optimal. Ini dikarenakan di Desa Kembang belum ada kegiatan seperti alternatif pekerjaan saat bencana terjadi. Kondisi ini menjadikan saat terjadi bencana masyarakat tidak bekerja dan hanya mengandalkan bantuan. Sementara itu, sebanyak $51 \%$ responden yang menyatakan efektif merupakan masyarakat bermatapencaharian selain petani dan nelayan, sehingga ketahanan ekonominya masih terjaga di mana saat terjadi bencana kelompok masyarakat ini tidak terdampak dan masih dapat bekerja. Hanya saja sebagian dari mereka harus mengeluarkan biaya lebih untuk berganti moda transportasi agar dapat pergi bekerja maupun biaya untuk memindahkan kendaraan mereka ke tempat yang tidak terdampak bencana sehingga tetap dapat digunakan untuk pergi bekerja.

6) Perlindungan Kesehatan kepada Kelompok Rentan

Dari 100 responden, sebanyak $66 \%$ responden menyatakan bahwa perlindungan kesehatan kepada kelompok rentan di Desa Kembang sudah efektif. Desa Kembang telah memiliki program perlindungan kesehatan dan santunan sosial kepada kelompok rentan, misalnya Program Lansia. Program tersebut juga sudah memiliki skema yang jelas dan sudah ada pengelolaan serta mekanisme pelaksanaan program. Saat terjadi bencana di Desa Kembang juga sudah ada posko-posko untuk cek kesehatan dan pembagian obat-obatan secara gratis. Namun, penerima manfaat program ini belum merata sehingga masih ada 44\% masyarakat yang menyatakan bahwa perlindungan kesehatan kepada kelompok rentan di Desa Kembang belum efektif.

7) Pengelolaan Sumber Daya Alam untuk Pengurangan Risiko Bencana
Dari 100 responden, sebanyak 46\% responden menyatakan bahwa pengelolaan SDA untuk pengurangan risiko bencana di Desa Kembang telah efektif. Karena di Desa Kembang telah memiliki kegiatan-kegiatan pengelolaan sumber daya alam sebagai upaya pengurangan risiko bencana serta memiliki mekanisme untuk menjamin keberlanjutan pengelolaan sumber daya alam untuk pengurangan risiko bencana dalam kurun waktu yang panjang. Kegiatan ini seperti perizinan penambangan pasir yang dilakukan di Sungai Grindulu, tepatnya di Dusun Bubakan. Penambangan pasir yang diizinkan adalah lebih dari 700 meter dari bibir sungai. Peraturan inipun telah disosialisasikan kepada warga desa. Sedangkan 54\% responden menyatakan bahwa pengelolaan SDA untuk pengurangan risiko bencana di Desa Kembang belum efektif karena ketidaktahuan akan adanya mekanisme untuk menjamin keberlanjutan pengelolaan sumber daya alam untuk pengurangan risiko bencana dalam kurun waktu yang Panjang di desanya.

\section{8) Pengelolaan Aset Produktif Utama Masyarakat \\ Di Desa Kembang telah memiliki gudang} bersama, namun belum memiliki kegiatan yang jelas untuk melakukan pengelolaan aset produktif masyarakat. Sebanyak $63 \%$ responden menyatakan bahwa pengelolaan aset produktif utama masyarakat di Desa Kembang tidak efektif.

\section{Penyelenggaraan Penanggulangan Bencana Desa Kembang}

Indikator dalam penelitian ini adalah Peta dan kajian risiko, peta dan jalur evakuasi, serta tempat pengungsian; sistem peringatan dini; pelaksanaan mitigasi struktural (fisik); pola ketahanan ekonomi untuk mengurangi kerentanan masyarakat; perlindungan kesehatan kepada kelompok rentan; pengelolaan sumber daya alam (SDA) untuk PRB, serta perlindungan aset produktif utama masyarakat. Hasil skoring dapat dilihat pada Tabel 6 .

Tabel 6. Skoring penilaian penyelenggaraan penanggulangan bencana Desa Kembang

\begin{tabular}{|c|c|c|c|}
\hline Indikator & $\begin{array}{c}\text { Tidak } \\
\text { Efektif }\end{array}$ & $\begin{array}{l}\text { Cukup } \\
\text { Efektif }\end{array}$ & Efektif \\
\hline $\begin{array}{l}\text { Peta dan kajian } \\
\text { risiko }\end{array}$ & 20 & 11 & 69 \\
\hline $\begin{array}{ll}\text { Peta dan jalur } \\
\text { evakuasi, } \\
\text { tempat }\end{array}$ & 17 & 9 & 74 \\
\hline $\begin{array}{l}\text { Sistem peringatan } \\
\text { dini }\end{array}$ & 27 & 40 & 33 \\
\hline
\end{tabular}




\begin{tabular}{lccc}
\hline $\begin{array}{l}\text { Pelaksanaan } \\
\text { mitigasi struktural } \\
\text { (fisik) }\end{array}$ & 14 & 19 & 67 \\
\hline $\begin{array}{l}\text { Pola ketahanan } \\
\text { ekonomi untuk } \\
\text { mengurangi } \\
\text { kerentanan } \\
\text { masyarakat }\end{array}$ & 49 & 16 & 35 \\
\hline $\begin{array}{l}\text { Perlindungan } \\
\text { kesehatan kepada } \\
\text { kelompok rentan }\end{array}$ & 18 & 16 & 66 \\
$\begin{array}{l}\text { Pengelolaan } \\
\text { sumber daya alam } \\
\text { (SDA) untuk PRB }\end{array}$ & 34 & 20 & 46 \\
\hline $\begin{array}{l}\text { Perlindungan aset } \\
\text { produktif utama } \\
\text { masyarakat }\end{array}$ & 63 & 3 & 34 \\
\hline
\end{tabular}

Berdasarkan Tabel 6 dapat diketahui bahwa peta dan jalur evakuasi, serta tempat pengungsian merupakan indikator yang paling efektif yaitu dengan persentase sebesar 74\%. Aspek-aspek dalam indikator ini memang sudah lengkap, seperti peta jalur evakuasi, tempat pengungsian, dan praktik simulasi evakuasi dan penyelamatan diri bersama warga desa. Indikator paling efektif lainnya disusul oleh peta dan kajian risiko (69\%) serta pelaksanaan mitigasi struktural $(67 \%)$. Adapun indikator yang tidak atau belum efektif adalah perlindungan aset produktif utama masyarakat $(63 \%)$ dan pola ketahanan ekonomi untuk mengurangi kerentanan masyarakat (49\%).

Dari hal ini dapat disimpulkan, bahwa dari segi perencanaan penyelenggaraan penanggulangan bencana telah dipersiapkan dengan baik dengan membuat dokumen kajian risiko bencana dan tempat dan jalur evakuasi bencana. Namun, jika dilihat dari aspek ketahanan ekonomi atau terkait produktivitas masyarakat masih belum optimal. Padahal, aspek ekonomi adalah salah satu aspek yang paling terdampak bencana dan perlu diantisipasi langkah tindak lanjutnya.

Jika dikompilasikan kedelapan indikator yang digunakan, maka hasil skoring mengenai penyelenggaraan penanggulangan bencana didapatkan hasil skoring mengenai efektivitas penyelenggaraan penanggulangan bencana di Desa Kembang yang menyatakan sudah efektif. Detail perhitungan efektivitas terlihat di Tabel 7.

Tabel 7. Efektivitas penyelenggaraan penanggulangan bencana Desa Kembang

\begin{tabular}{|c|c|c|c|c|}
\hline \multicolumn{3}{|c|}{ Rating Scale } & \multirow{2}{*}{$\begin{array}{c}\text { Rating } \\
\text { Scale } \\
\text { (Total) }\end{array}$} & \multirow{2}{*}{$\begin{array}{c}\text { Efektivitas } \\
\text { Variabel }\end{array}$} \\
\hline $\begin{array}{c}\text { TE } \\
(\text { TE } \times 1) \\
\end{array}$ & $\begin{array}{c}\mathrm{CE} \\
(\mathbf{C E} \times 2) \\
\end{array}$ & $\begin{array}{c}E \\
(\mathbf{E} \times 3)\end{array}$ & & \\
\hline 30 & 34 & 159 & 223 & Efektif \\
\hline
\end{tabular}

Dari hasil skoring tersebut dapat diketahui bahwa penyelenggaraan penanggulangan bencana Desa Kembang telah efektif karena skor penilaianya berada pada rating scale 223 , di mana skor 201-300 merupakan daerah respon efektif. Jika dilihat dari perhitungan efektivitas per indikator di Tabel 6, meskipun terdapat indikator yang belum efektif nilainya, namun terdapat empat indikator yang bernilai diatas $60 \%$, yaitu peta dan jalur evakuasi, serta tempat pengungsian, peta dan kajian risiko, pelaksanaan mitigasi struktural, dan perlindungan kesehatan kepada kelompok rentan. Hal ini sejalan dengan temuan Rahman (2017) dan Buchari et al. (2019) bahwa kapasitas suatu wilayah dalam PRB dapat dilihat dari ketersediaan kelembagaan PRB, ragam sumber daya (dana, SDM, dan prasarana) serta adanya kajian risiko bencana di daerah yang memuat data bahaya dan kerentanan. Diperlukan tata kelola yang baik, baik menyangkut kapasitas SDM yang paham bencana, ketersediaan sumber pendanaan dan sarana prasarana penunjang PRB (Adinata et al., 2017). Lebih lanjut, Buchari (2019) dan Putra \& Diatmika (2019) menyatakan bahwa selain dukungan kebijakan untuk mitigasi bencana, juga perlu peran kelembagaan yang kuat melalui kerjasama antar pemangku kepentingan dalam penanggulangan bencana. Pemerintah berperan dalam fungsi teknis dan finansial sedangkan peran masyarakat aktif masyarakat diperlukan dalam implementasi program (Wardani \& Putra, 2016).

Sementara itu, untuk indikator yang tidak efektif merupakan indikator yang terkait dengan ketahanan ekonomi masyarakat untuk mengurangi kerentanan. Padahal, menurut Septiana (2013) masyarakat perlu memiliki alternatif mata pencaharian sebagai bentuk ketahanan ekonomi di kala bencana, seperti beralih ke sektor sekunder yang tidak terlalu bergantung terhadap alam. Lebih lanjut, keberhasilan program Destana juga memerlukan kesiapsiagaan masyarakat dan berbagai pihak baik dari aspek pengetahuan, sikap, rencana tanggap darurat, dan sistem peringatan bencana (Febriana et al., 2015)

\section{KESIMPULAN}

Penyelenggaraan penanggulangan bencana Desa Kembang telah efektif karena dukungan dari beberapa indikator, yaitu peta dan jalur evakuasi, serta tempat pengungsian, peta dan kajian risiko, pelaksanaan mitigasi struktural, dan perlindungan kesehatan kepada kelompok rentan dengan persentase nilai di atas $60 \%$. Sementara itu, untuk indikator yang bernilai tidak efektif adalah perlindungan aset produktif utama masyarakat dan 
pola ketahanan ekonomi untuk mengurangi kerentanan masyarakat karena sekitar 50\% masyarakat menilai bahwa kedua indikator tersebut belum diupayakan secara maksimal. Sehingga perlu adanya alternatif mata pencaharian sebagai bentuk ketahanan ekonomi di kala bencana, seperti beralih ke sektor sekunder yang tidak terlalu bergantung terhadap alam.

\section{DAFTAR PUSTAKA}

Adinata, I., Hakim, M. L., \& Utaminingsih, A. (2017). Analisis Tata Kelola Desa Tangguh Bencana dalam Perspektif Pengurangan Risiko Bencana (Studi di Desa Banjarsari Kecamatan Gabus Kabupaten Pati). Journal of Governance and Policy, 3(1), 1-12.

Aini, N., Ulfah, I. F., \& Afala, L. M. (2018). Efektivitas Program Desa Tangguh Bencana Di Desa Sirnoboyo Kecamatan Pacitan Kabupaten Pacitan Tahun 2017. Journal of Governance and Policy, 4(2), 50-61.

BNPB (2012). Peraturan Kepala BNPB Nomor 1 Tahun 2012 tentang Pedoman Umum Desa/Kelurahan Tangguh Bencana. Jakarta: BNPB.

BPBD Kabupaten Pacitan. (2014). Dokumen Kajian Resiko Bancana Kabupaten Pacitan Tahun 2014-2018. Pacitan: BPBD.

Buchari, A., Santoso, M. B., \& Marlina, N. (2017). Pengembangan Kapasitas Kelembagaan Desa Tangguh Bencana di Kabupaten Garut (Studi Kasus di Desa Pasawahan Kecamatan Tarogong Kaler). Jurnal Analisis Dan Kebijakan Publik, 3(1), 1-13.

Buchari, R. A. (2019). Manajemen Mitigasi Bencana dengan Kelembagaan Masyarakat di Daerah Rawan Bencana Kabupaten Garut Indonesia. Sembadha 2019: Seminar Nasional Dan Hasil Pengabdian Kepada Masyarakat, 1-7.

Buchari, R. A., Darmawan, I., \& Ramdhan, K. M. (2019). Institutional Capacity Building Of Disaster-Resilient Village in Garut Regency. Proceedings IAPA Annual Conference, 103117. https://doi.org/10.30589/proceedings.2019.2 33

Febriana, Sugiyanto, D., \& Abubakar, Y. (2015). Kesiapsiagaan Masyarakat Desa Siaga Bencana Dalam Menghadapi Gempa Bumi di Kecamatan Meuraxa Kota Banda Aceh. Jurnal Ilmu Kebencanaan, 2(3), 41-49.

Idhom, A. M. (2017, November 28). Banjir dan Longsor di Pacitan: 11 Orang
Tewas dan 13 Desa Terendam. Retrieved from Sosial Budaya: tirto.idOktari, R. S. (2019). Peningkatan Kapasitas Desa Tangguh Bencana. Jurnal Pengabdian Kepada Masyarakat, 4(2), 189. https://doi.org/10.22146/jpkm.29960

Pinakesti, N. H., \& Husein, R. (2018). Persepsi Masyarakat Terhadap Program Desa Tangguh Bencana di Desa Pondokrejo Kecamatan Tempel Kabupaten Sleman Tahun 2017. http://repository.umy.ac.id/bitstream/handle /123456789/18884/10.NASKAH

PUBLIKASI.pdf?sequence $=1 \&$ isAllowed $=$ $\mathrm{y}$

Pemerintah Kabupaten Pacitan. (2010). Gambaran Umum Rencana Tata Ruang Wilayah Tahun 2009 - 2028. Pacitan: Sekertaris Daerah.

Pemerintah Kabupaten Pacitan. (2020). Kecamatan Pacitan dalam Angka 2019. Pacitan: Badan Pusat Statistik Kabupaten Pacitan.

Putra, I. W. K. E., \& Diatmika, I. P. G. (2019). Rintisan Desa Tangguh Bencana (Destana) Di Desa Gitgit, Kecamatan Sukasada, Kabupaten Buleleng. Jurnal Ilmiah Ilmu Sosial, 4 4(2), 161-166. https://doi.org/10.23887/jiis.v4i2.16531

Rachmawati, Y., Kismartini, \& Suharyanto. (2018). The Flood Disaster Management Model in Wonosari Village Semarang City. E3S Web of Conferences, 73, 4-7. https://doi.org/10.1051/e3sconf/201873080 31

Rahman, A. Z. (2017). Kapasitas Daerah Banjarnegara dalam Penanggulangan Bencana Alam Tanah Longsor. Jurnal Ilmu Sosial, 16(1), 1-8.

Septiana, T. C. (2013). Lesson Learned Peralihan Mata Pencaharian Masyarakat Sebagai Ketahanan Terhadap Perubahan Iklim Kelurahan Mangunharjo. Jurnal Wilayah Dan Lingkungan, 1(2), 123-140. https://doi.org/10.14710/jwl.1.2.123-140

Setyawati, D. N., \& Pambudi, A. (2018). Efektivitas Program Desa Tangguh Bencana di Desa Argomulyo, Cangkringan, Sleman, DIY. Adinegara, 7, 1100-1110.

Sugiyono. (2016). Metode Penelitian Kuantitatif, Kualitatif, dan $R \& D$. Bandung: Alfabeta

Susilowati, F., \& Siswanta, L. (2016). Peningkatan Kapasitas Masyarakat Dalam Menghadapi Risiko Bencana Berbasis Gender. Jurnal SEMAR, 5(1), 41-49.

Taslim, I., \& Akbar, M. F. (2019). Koordinasi Publik untuk Pengurangan Risiko Bencana 
(PRB) Banjir pada Pelaksanaan Pembangunan Berkelanjutan Gorontalo. Jurnal Wilayah Dan Lingkungan, 7(2), 63 78. https://doi.org/10.14710/jwl.7.2.29-44

Wardani, N. R., \& Putra, D. F. (2016). Strengthening Local Capacity for Disaster Risk Reduction (Case Study: Disaster Resilient Village in Batu City, East Java, Indonesia). Advances in Social Science, Education and Humanities Research, 79, 13-17. https://doi.org/10.2991/icge 16.2017 .3 


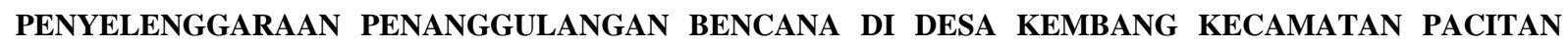
KABUPATEN PACITAN 